\title{
Tata laksana ICU Krisis Miasthenia pada Pasien Tuberkulosis Paru dengan Penyulit Ventilator Associated Pneumonia (VAP)
}

\author{
Titik Setyawati, ${ }^{1}$ Reza Widianto Sujud, ${ }^{2}$ Indriasari ${ }^{2}$ \\ ${ }^{1}$ SMF Anestesi dan Terapi Intensif RSUD Dr. Drajat Prawiranegara, Serang Banten, \\ ${ }^{2}$ Departemen Anestesi dan Terapi Intensif Fakultas Kedokteran Universitas Padjajaran/ \\ Rumah Sakit Umum Pusat Dr. Hasan Sadikin Bandung
}

\begin{abstract}
Abstrak
Krisis miastenia adalah eksaserbasi akut miastenia gravis dengan kelemahan yang melibatkan otot-otot pernapasan sehingga terjadi kegagalan napas akut dan memerlukan dukungan ventilasi mekanik. Krisis miastenia merupakan komplikasi miastenia gravis yang paling berbahaya dan mengancam jiwa bila tidak segera ditangani. Timbulnya krisis miastenia dapat dipicu oleh berbagai faktor, di antaranya infeksi dan penggunaan antibiotik aminoglikosid. Tata laksana Intensive Care Unit (ICU) pasien krisis miastenia meliputi tata laksana terhadap kegawatan respirasi, tata laksana terhadap miastenia gravis, dan tata laksana terhadap faktor peyulit. Intubasi endotrakeal dan dukungan ventilasi mekanis merupakan pilihan utama tata laksana kegawatan respirasi. Plasmaparesis adalah salah satu metode terapi yang terbukti efektif dan efisien selain pemberian agen anticholinesterase, terapi imunomodulator cepat, agen imunosupresif, dan timektomi. Terapi standar untuk menanggulangi tuberkulosis paru dengan obat antituberkulosis berdasar atas pedoman penatalaksanaan tuberkulosis serta terapi ventilator associated pneumonia (VAP) dengan pilihan antibiotik sesuai dengan hasil kultur bakteri. Dukungan nutrisi yang adekuat juga diperlukan untuk menunjang keberhasilan terapi. Dengan assessment dini dan terapi yang adekuat diharapkan dapat memperbaiki prognosis pasien krisis miastenia. Pada laporan kasus ini kami sajikan tata laksana ICU pasien krisis miastenia gravis yang dipicu oleh tuberkulosis paru dengan penyulit VAP yang dirawat di ICU RSHS Bandung pada bulan Oktober-November 2019.
\end{abstract}

Kata kunci: Krisis miasthenia, plasmaparesis, tuberkulosis paru, ventilator associated pneumonia

\section{ICU Management of Myasthenic Crisis in Pulmonary Tuberculosis Patients with Ventilator Associated Pneumonia Complications}

\begin{abstract}
Myasthenic crisis is an acute exacerbation of myasthenia gravis with a weakness that involves the respiratory muscles, leading to acute respiratory failure that requires mechanical ventilation support. Myasthenia crisis is the most dangerous and life-threatening complication of myasthenia gravis if not treated immediately. The emergence of myasthenic crisis can be triggered by various factors, including infection and aminoglycoside use. Intensive Care Unit (ICU) management of myasthenic crisis patients includes management of respiratory emergencies, management of myasthenia gravis, and management of complicating factors. Endotracheal intubation and mechanical ventilatory support are the main choices in the management of respiratory emergencies. Plasmaparesis is one of the proven and effective therapeutic methods in addition to anticholinesterase agent, rapid immunomodulatory therapy, immunosuppressive agent, and thymectomy. Standard therapy for treating pulmonary tuberculosis includes anti-tuberculosis drugs, as stated in tuberculosis management guidelines, and Ventilator Associated Pneumonia (VAP) therapy with antibiotic options according to bacterial culture results. Adequate nutritional support is also needed to support the success of therapy. With early assessment and adequate therapy, it is expected that the prognosis of myasthenic crisis patients will be improved. This case report presented the management of myasthenia gravis crisis triggered by pulmonary tuberculosis with VAP complications in patients treated at the ICU of Dr. Hasan Sadikin General Hospital Bandung, Indonesia, from October to November 2019.
\end{abstract}

Key words: Myastheniac crisis, plasmapharesis, pulmonary tuberculosis, ventilator associated pneuminia

Korespondensi: Titik Setyawati, dr., SpAn. M. Kes, SMF Anestesi dan Terapi Intensif RSUD Dr. Drajat Prawiranegara, Jl. Rumah Sakit Umum No.1, Kotabaru, Kec. Serang, Kota Serang, Banten 42112, Tlpn 0254-208833, Email: setyawatititik@yahoo.com 


\section{Pendahuluan}

Miastenia gravis adalah kelainan autoimun yang ditandai oleh kelemahan abnormal dan progresif pada otot rangka yang dipergunakan secara terus menerus disertai dengan kelelahan saat beraktivitas, kekuatan otot akan pulih kembali tidak lama setelah penderita beristirahat. Penyakit ini timbul karena gangguan dari transmisi sinap atau pada neuromuscular junction yang merupakan kelainan autoimun saraf perifer diakibatkan pembentukan antibodi terhadap reseptor pascasinaptik asetilkolin (ACh) nikotinik pada myoneural junction. Penurunan jumlah reseptor ACh ini menyebabkan penurunan kekuatan otot yang progresif ditandai dengan kelemahan yang berfluktuasi dan melibatkan kombinasi yang bervariasi dari otot okular, bulbar, ekstremitas, dan otot pernapasan. Penurunan kekuatan otot ini dapat pulih setelah beristirahat. Miastenia gravis adalah kelainan primer paling umum dari transmisi neuromuskular dan salah satu kelainan neurologis yang dapat diobati..$^{1-3}$

Prevalansi miastenia gravis adalah 14 per 100.000 populasi (kira-kira 17.000 kasus) di Amerika. Pada kelompok usia kurang dari 40 tahun, penyakit ini didapatkan 3 kali lipat lebih banyak pada wanita dibanding dengan pria, namun pada usia yang lebih tua didapatkan persentase yang sama. Berdasar atas laporan Riset Kesehatan Dasar (Riskesdas) 2010, diperkirakan 1 kasus dari 100.000. Data yang didapatkan di rumah sakit Cipto Mangunkusumo Jakarta terdapat 94 kasus dengan diagnosis miastenia gravis pada periode tahun $2010-2011 .^{4}$

Krisis miastenia didefinisikan sebagai eksaserbasi akut miastenia gravis (MG) yang mengancam jiwa dengan kelemahan yang melibatkan otot-otot pernapasan sehingga mengakibatkan kegagalan napas akut dan memerlukan bantuan ventilasi mekanik. Krisis miasthenia biasa terjadi dalam 2 tahun pertama setelah onset terkena miastenia gravis (pada sekitar 74\% kasus). Pada beberapa pasien, krisis miastenia dapat merupakan presentasi awal dari miastenia gravis. Selain merupakan bagian dari perjalanan alami miastenia gravis, krisis miastenia juga dapat dipicu oleh berbagai masalah lain sebagai penyebab utama, di antaranya adalah: infeksi, kelainan elektrolit (termasuk kalsium/ fosfat/ magnesium), penyakit tiroid (baik hipo atau hipertiroid), bedah/trauma, kehamilan, persalinan, tapering obat imunosupresif (kortikosteroid) dan obat-obatan: antibiotik (aminoglikosida, florokuinolon, makrolid, penisilin, nitrofurantoin, klindamisin, sulfonamid). Obat kardiovaskular di antaranya calsium chanel blokers, beta blokers, prokainamid, lidokain, selain itu ada magnesium, media kontras, dan thyroid replacement ${ }^{1,5}$

Tuberkulosis (TB) paru adalah tuberkulosis yang menyerang jaringan organ paru (tidak termasuk pleura) yang disebabkan oleh infeksi Mycobacterium tuberculosis complex. Insidens TB paru secara signifikan lebih tinggi pada pasien dengan miastenia gravis. Strategi skrining yang hati-hati untuk TB harus dipertimbangkan pada pasien berisiko tinggi dengan miastenia gravis. ${ }^{6,7}$

Ventilator associated pneumonia atau VAP didefinisikan sebagai pneumonia yang terjadi $>48$ jam setelah intubasi endotrakeal. Kejadian hospital acquired pneumonia (HAP) rerata 5-15 setiap 1.000 kasus rawat di rumah sakit, sedangkan di unit rawat intensif sekitar $25 \%$ dan $70-80 \%$ episode pneumonia ini terjadi saat menggunakan ventilator (VAP). Data dari beberapa rumah sakit pendidikan paru di Indonesia didapatkan bakteri patogen terbanyak penyebab HAP termasuk VAP di dalamnya, yaitu klebsiella pneumoniae, acinetobacter baumanii, staphylococcus aerus, dan pseudomonas aeruginosa. ${ }^{8}$

Plasmaparesis atau istilah lainnya adalah plasma exchange (PLEX) adalah prosedur plasma dipisahkan dari sel-sel darah dan diganti dengan fresh frozen plasma, produk darah, atau plasma subtitute. ${ }^{9}$

Pemahaman patofisiologi krisis miastenia sangat diperlukan untuk tata laksana krisis ini. Tata laksana ICU pasien krisis miastenia meliputi tata laksana terhadap kegawatan respirasi, tata laksana terhadap miastenia gravis, tata laksana terhadap faktor penyulit, 
dan dukungan nutrisi.

\section{Laporan Kasus}

Pada tanggal 26 Oktober 2019, pukul 20.00 seorang laki-laki usia 33 tahun datang dengan keluhan sulit menelan sejak 3 hari sebelum masuk rumah sakit (SMRS).

Pasien mengeluh sering mengeluarkan liur, sesak napas, dan sulit membuka kelopak mata pada siang hari, pandangan ganda dan bicara terdengar sengau. Kelemahan keempatanggota gerak tubuh, kebas sesisi, mulut mencong dan bicara pelo, pandangan gelap sesaat, pusing berputar, telinga berdengung disangkal oleh pasien. Pasien sudah mengetahui menderita miestenia gravis (MG) sejak bulan Juni 2019 dan diberikan obat mestinon 4x1 tablet, sebulan setelah menderita MG pada bulan Agustus pasien dirawat di RS Al-Ihsan dengan tuberkulosis paru (TB paru), dan saat ini pasien sedang dalam fase lanjutan obat anti tuberkulosis (OAT).

Pada pemeriksaan fisis awal didapatkan kesadaran komposmentis dengan suhu $36,1^{\circ} \mathrm{C}$, BB $45 \mathrm{~kg}$, TB $165 \mathrm{~cm}$, dan BMI pasien 16,7 $\mathrm{kg} / \mathrm{m}^{2}$ (underweight). Pada survei primer didapatkan airway clear, breathing respirasi 28x/menit, pergerakan dinding dada stabil, tidak didapatkan ronki maupun wheezing, circulation tekanan darah 120/80 mmHg, nadi $89 \mathrm{x} / \mathrm{mnt}$, disability glasgow coma scale (GCS) E4M6V3 dan didapatkan gangguan nervus okulomotor (kelopak mata kanan ptosis, pandangan mata terasa ganda), sulit menelan, tangan dan kaki melemah.

Pemeriksaan laboratorium: $\mathrm{Hb} 13,7 \mathrm{~g} / \mathrm{dL}$, leukosit: 8,06 sel/mm, Ht 38,6\%, trombosit $23110^{3} / \mathrm{uL}$; GDS $95 \mathrm{mg} / \mathrm{dL}$; ureum 15,9 mg/ $\mathrm{dL}$; kreatinin 0,75 mg/dL; AGD-elektrolit: pH 7,436; $\mathrm{PCO}_{2} 38,5$ mmHg; $\mathrm{PO}_{2} 88,1 \mathrm{mmHg}$; $\mathrm{HCO}_{3}$ 26,1; $\mathrm{TCO}_{2}$ 27,3; BE -2,5; $\mathrm{SpO}_{2}$ 96,8; Na 133; K 3,8; Ca 4,53; Mg: 2,5 mmol/L. Hasil pemeriksaan foto rontgen toraks menunjukkan kesan TB paru lama aktif dan tidak tampak kardiomegali.

Diagnosis kerja impending krisis miastenia gravis dengan tuberkulosis. Mendapat terapi neostigmin; sulfas atropin $=10: 5 \mathrm{Amp} / 24$ jam, $\mathrm{NaCl}$ 0,9\% $1.500 \mathrm{cc} / 24$ jam, obat anti tuberkulosis lanjutan fixed dose combination $1 \mathrm{x} 3$ tablet (3x/minggu), Oksigen 8-10 L/mnt nonrebreathing oksigen masker (NRM), pasang naso gastric tube (NGT), rencana plasmafaresis

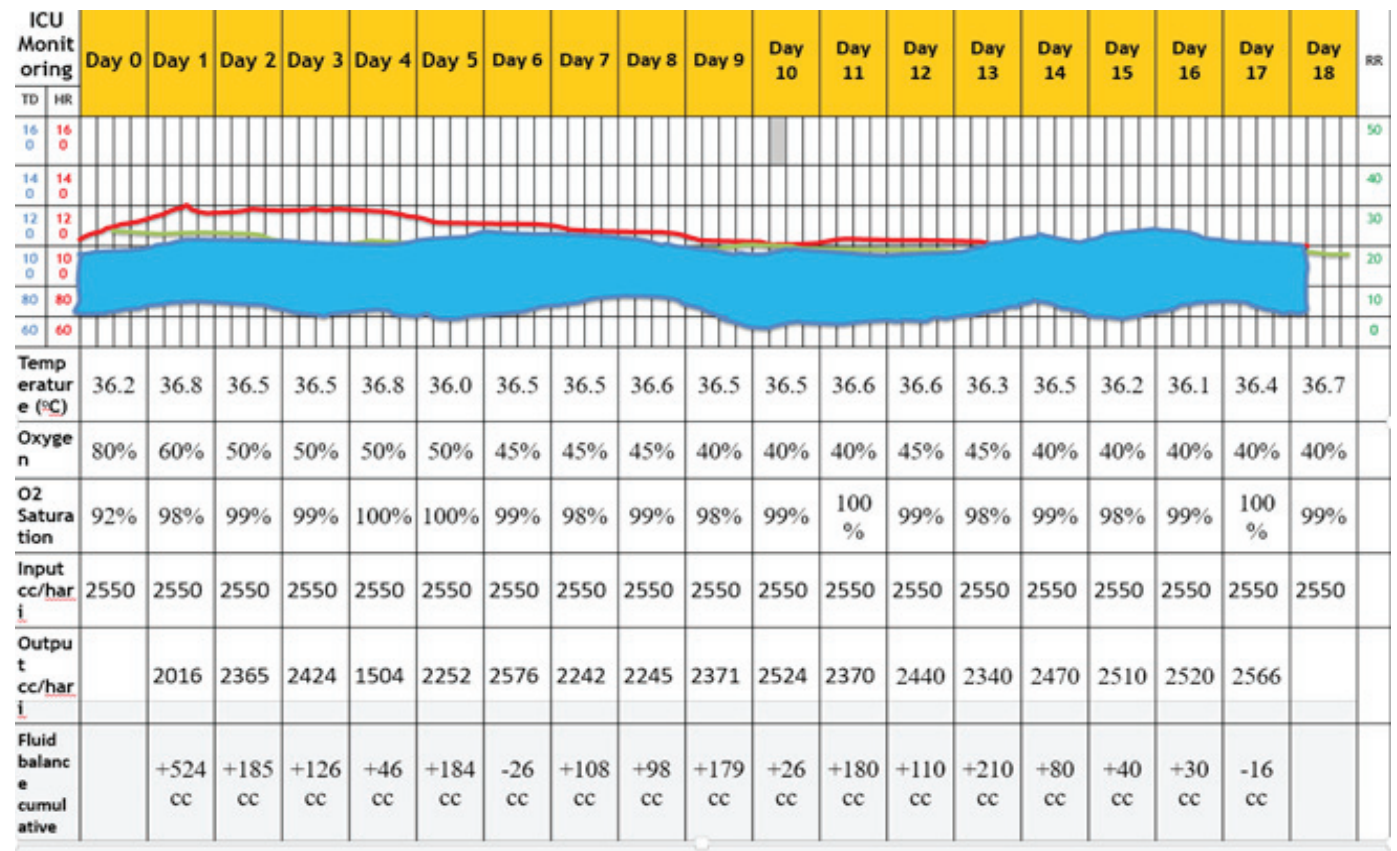

Gambar 1 Flowchart Monitoring ICU 


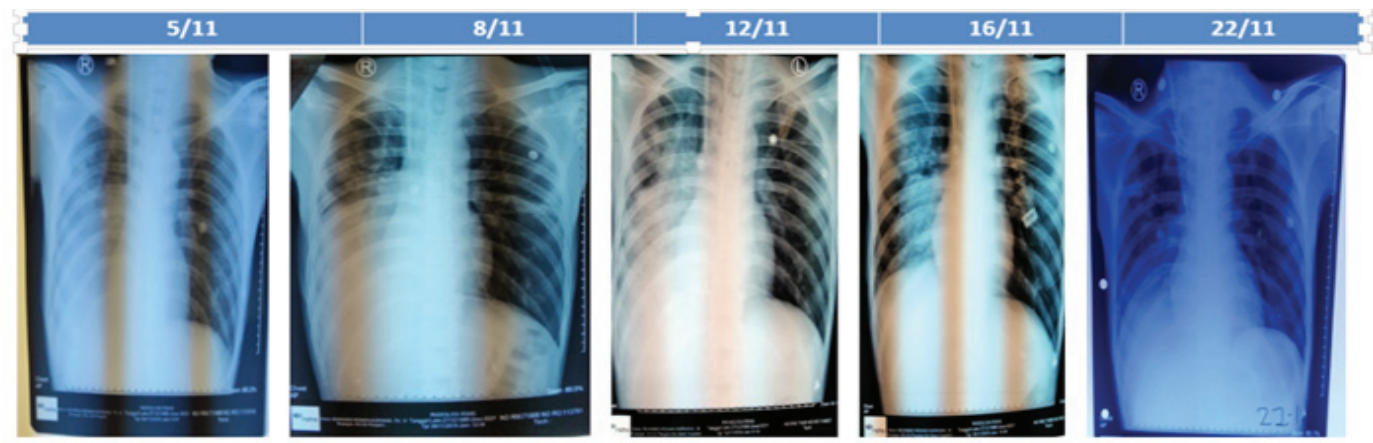

Gambar 2 Evaluasi Rontgen Toraks Pasien

Ket hasil foto toraks:

5/11 kesan pleura pneumonia dekstra ,TB paru aktif

8/11 kesan pleuro pneumonia dekstra perburukan, TB paru aktif

12/11 kesan pleuropneumonia dekstra sedikit perbaikan, TB paru aktif

16/12 kesan pleuru pneumonia ada perbaikan, TB paru mulai perbaikan

$22 / 12$ infiltrat minimal, ada perbaikan dibanding dengan foto sebelumnya.

Sumber: dokumentasi pribadi

6x, rawat ruang semi intensif. Pada 1 jam pertama direncanakan pemeriksaan sampel sputum dan darah.

Selama 4 hari pasien dirawat di bangsal Fresia 2 dengan diagnosis impending krisis miastenia gravis dengan TBC paru dalam terapi obat antituberkulosis (OAT) fase lanjutan bulan ketiga. Pada hari perawatan kelima (31 Oktober 2019), dipindah ke High Care Unit (HCU) oleh karena keluhan sesak bertambah dengan laju napas lebih dari 30x/ menit dan saturasi oksigen $87 \%$ menggunakan nonrebreathing oxigen mask (NRBM)10 liter per menit, kemudian dilakukan intubasi dengan persetujuan keluarga dengan endotracheal tube (ETT) + jackson rees $\mathrm{O}_{2} 81 /$ menit (bagging). Hasil pemerikasaan sputum tidak ditemukan pertumbuhan kuman. Hasil laboratorium: $\mathrm{Hb} 14,1 \mathrm{~g} / \mathrm{dL}$, sputum hasil $(-)$ tidak ditemukan kuman, leukosit 6,54

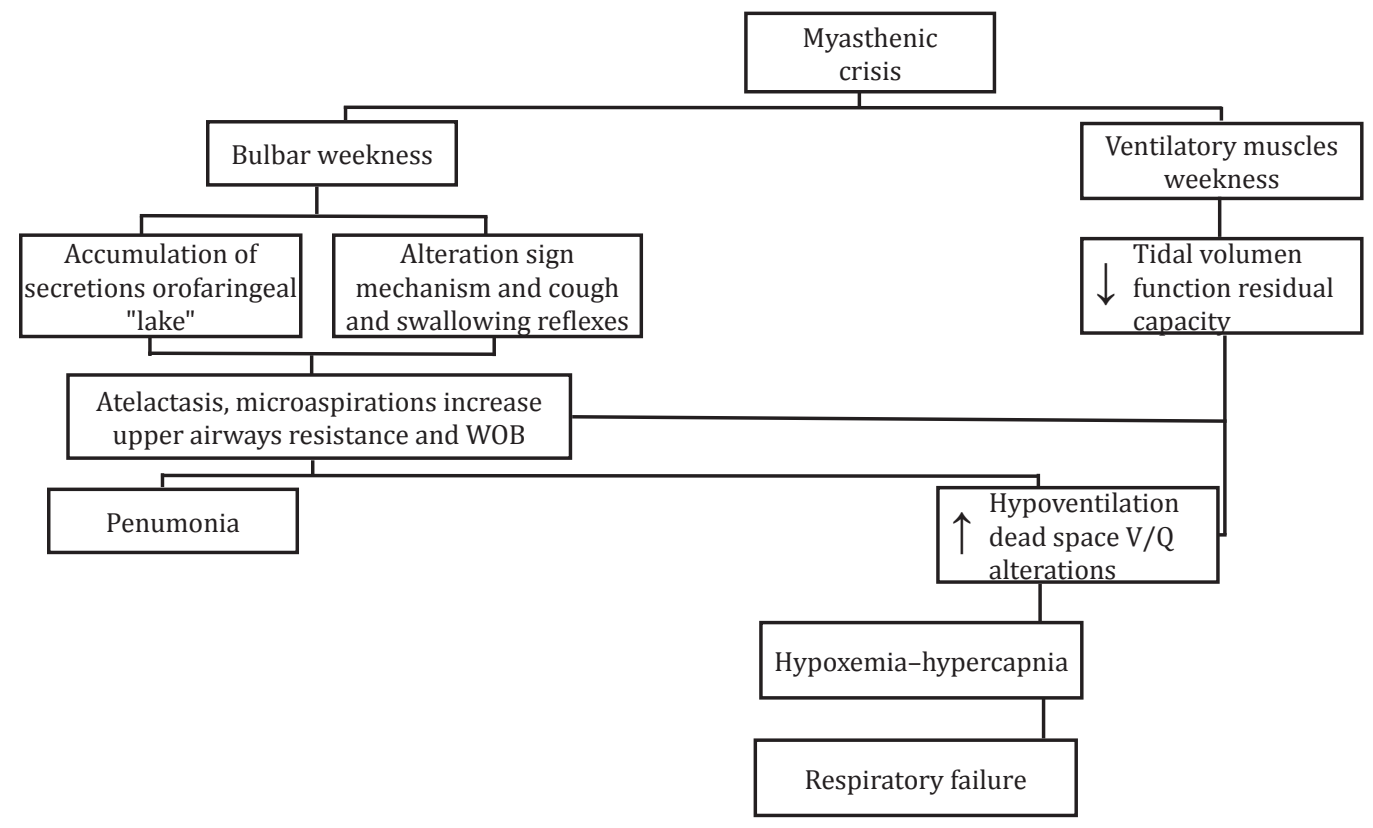

Gambar 3 Patofisiologi Gagal Napas pada Krisis Miastenia

Sumber: Godoy dkk. ${ }^{11}$ 
sel/mm ; eritrosit 4,47 juta/uL; Ht 39,9\%; trombosit $215.10^{3 / u L ;}$ elektrolit: natrium: 137 ; kalium: 4,2; kalsium 5,242; AGD: pH 7,46; $\mathrm{PCO}_{2} 47$ mmHg; $\mathrm{PO}_{2} 145,9$ mmHg; $\mathrm{HCO}_{3} 28,4$; $\mathrm{TCO}_{2}$ 29,97; BE 3,3; $\mathrm{SpO}_{2}$ 99,3. Diagnosis krisis miastenia yang dengan tuberkulosis paru karena tempat perawatan ICU penuh sehingga pasien belum dipindahkan.

Pada perawatan hari ke-9 (4 November 2019) pasien pindah perawatan di ICU, pukul 12.30 keadaan umum pasien tampak sakit berat, GCS 10 dengan intubasi, respirasi ETT menggunakan ventilator mode $\mathrm{PSIMV} \mathrm{FiO}_{2}$ 60\%, RR 18 PS: 12, hasil luaran TV 350-430, $\mathrm{SpO}_{2} 99 \%$, tekanan darah $100 / 60 \mathrm{mmHg}$, nadi $110 \mathrm{x} /$ menit, suhu $36,5^{\circ} \mathrm{C}$.

Pada perawatan ICU hari kedua (6 November 2019), subjektif: pasien tampak sesak napas bertambah, objektif: GCS sulit dinilai, sekret purulen, ronki di kedua lapang paru, GCS E3VtM4,TD 110/60 mmHg, HR $105 \mathrm{x} / \mathrm{mnt}$, suhu 36,8 derajat $\mathrm{C}$ skor richmond agitation sedation scale (RASS) -2, skor sequential organ failure assesment (SOFA) 3 , skor acute phisiology and chronic health evaluation (APACHE) II 8. Pada foto toraks terbaru didapatkan infiltrat di kedua lapang paru, kesan pleuropneumonia, kultur resistensi sputum menunjukkan kuman Klebsiella pneumoniae, sensitif ampisilin/sulbaktam, ceftriaxone, gentamisin, amikasin, piperacillin, cefotaxime, ceftazidime, cefepim, ciprofloxacin, cotrimoxasol, tigecylin, aztreonam, ertapenem, meropenem. Penilaian pada perawatan ICU hari kedua, yaitu respiratory failure et causa krisis miastenia dengan tuberkulosis paru, dengan penyulit ventilator-acquired pneumonia (VAP). Rencana pasien dilakukan plasmaferesis, ventilasi mekanik dengan strategi proteksi paru, Makanan: diet cair 1.100 kcal bertahap naik $1.350 \mathrm{kcal} / 24$ jam, Analgesi: morfin $10 \mathrm{mcg} / \mathrm{kgBB} / \mathrm{jam}$, parasetamol $3 \times 1.000$ $\mathrm{mg}$, Sedasi dengan midazolam $3 \mathrm{mg} / \mathrm{jam}$, tromboembolisme profilaktik: tidak diberikan, head of bed elevation: head up 30 derajat, ulcer preventif OMZ $3 \times 40 \mathrm{mg}$, glukosa kontrol: tidak diberikan, antikolinesterase dengan prostigmin: sulfas atropin (SA) $=5 \mathrm{mg}: 1,25 \mathrm{mg}$, metilprednisolon $62,5 \mathrm{mg} / 8 \mathrm{~J}$, plasmafaresis 6x, OAT lanjutan, $N$-acetilcystein $200 \mathrm{mg} / 8 \mathrm{~J}$, koreksi elektrolit, OAT (FDC) fase lanjutan.

Sampai dengan perawatan ICU hari ke14 dilakukan plasmaferesis sebanyak 6 kali, hasil laboratorium menunjukkan $\mathrm{Hb}$ 9,4 g/ $\mathrm{dL}$, diberikan transfusi PRC dua labu. Pada perawatan ICU hari ke-16 (20 November 2019) didapatkan VAP mengalami perbaikan, baik klinis dan laboratoriun yang ditandai sekret tidak ada, ronki di kedua lapang paru tidak ada, lemah badan berkurang, kekuatan otot meningkat, semakin kuat menggenggam, laboratorium: $\mathrm{Hb}$ 14,1 g/dL, leukosit 6,54 sel $/ \mathrm{mm}^{3}$, eritrosit 4,47 juta/uL, Ht 39,9\%, trombosit $21510^{3} / \mathrm{uL}$., elektrolit: natrium 137; kalium: 4,2; kalsium 5,242; AGD: pH 7,45; $\mathrm{PCO}_{2} 45 \mathrm{mmHg} ; \mathrm{PO}_{2} 145,9 \mathrm{mmHg} ; \mathrm{HCO}_{3}$

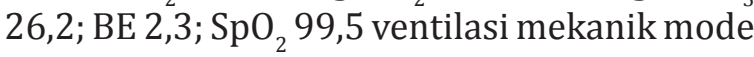
CPAP $\mathrm{FiO}_{2}: 40 \%$ respirasi spontan TV: 234450, PEEP 5, sampai pukul 10.00 dilakukan weaning ventilasi dengan T-Piece $6 \mathrm{lpm}$ sampai pukul 16.00 kemudian diganti dengan CPAP sampai pukul 22.00 dan dilanjutkan T-Piece lagi 6 lpm. Pada perawatan ICU hari ke-17 (22 November 2019), keluhan lemah berkurang, sesak berkurang, GCS $10 \mathrm{~T}$, respirasi spontan dengan T-Piece 6 lpm, tekanan darah 100/58 $\mathrm{mmHg}$, nadi $68 \mathrm{x} / \mathrm{menit}$, suhu $36,4^{\circ} \mathrm{C}$, pasien dipindahkan ke ruang rawat HCU Azalea.

\section{Pembahasan}

Tata laksana miastenia gravis diawali dengan penegakan diagnosis. Pada anamnesis pasien ini memang mempunyai riwayat penyakit miastenia gravis yang diderita sejak 5 bulan yang lalu (Juni 2019). Pasien juga sudah menjalani perawatan di rumah sakit sebanyak dua kali. Selama perawatan itu pasien diberikan mestinon tab 4x60 mg.

Pemeriksaan fisis diagnosis didapatkan peningkatan kelemahan umum atau gejala bulbar dan gejala neurologis yang diikuti dengan kelemahan otot pernapasan sebagai penanda awal. Pasien sejak di rumah sudah mengeluhkan sulit menelan, badannya lemah, pandangan mata ganda, mata kanan terasa berat untuk membuka, batuk, dan berangsur pasien juga mulai mengeluhkan napas yang 
sesak dan berat. Ciri miastenia gravis (MG) adalah kelemahan otot yang memburuk setelah periode aktivitas dan membaik setelah periode istirahat. ${ }^{11-13}$ Pada pasien ini juga didapatkan kelemahan otot yang memburuk saat beraktivitas dan berkurang setelah beristirahat, tetapi lama kelamaan gejala kelemahan otot semakin berat dan tidak berkurang dengan istirahat, kelemahan otot secara umum, diikuti kelemahan otot pernapasan hingga mengakibatkan kegagalan napas akut dan memerlukan bantuan ventilasi mekanik.

Terdapat beberapa manuver untuk dapat membantu diagnosis MG secara klinis; manuver enhanced, peek sign, abduksi lengan 2 menit, berhitung keras $1-50$, berhitung keras 1-20 dalam satu tarikan napas, elevasi tungkai selama 1,5 menit, dan lainnya. Ice pack test, tes ini murah, aman, tidak invasif dan sangat sensitif $(\sim 90 \%)$ dan spesifik $(\sim 80 \%)$. Selain anamnesis dan pemeriksaan klinis, diagnosis miastenia gravis dapat ditegakkan dengan beberapa uji klinis dan serologis. ${ }^{13}$ Karena kelemahan otot adalah gejala umum dari banyak gangguan lain, diagnosis miastenia gravis sering terlewatkan atau tertunda (kadang-kadang hingga dua tahun) pada orang yang mengalami kelemahan ringan atau pada orang-orang yang kelemahannya dibatasi hanya untuk beberapa otot. ${ }^{14,15}$ Pada pemeriksaan fisis pasien ini hanya dilakukan dengan abduksi selama 2 menit, berhitung keras 1-20 yang lama-lama melemah untuk penegakan diagnosis karena sebelumnya sudah terdiagnosis dan mendapat terapi MG, dengan riwayat minum obat tuberkulosis. ${ }^{1,5}$

Tata laksana krisis miastenia pada laporan kasus ini meliputi tata laksana terhadap kegawatan respirasi yang berupa gagal napas akibat kelemahan otot-otot pernapasan dari MG, tata laksana miastenia gravis, tata laksana tuberkulosis paru, faktor penyulit VAP dan terapi suportif, pemberian nutrisi yang adekuat. Gagal napas yang terjadi diatasi dengan bantuan ventulasi mekanik menggunakan strategi lung protektif akan mencegah obstruksi jalan napas, risiko aspirasi, atelektase, dan meminimalkan work of breathing (WOB). Pengobatan TB paru dengan FDC. ${ }^{1,5}$ Penggunaan ventilator yang lebih dari 48 jam akibat gagal napas di sebabkan oleh kelemahan otot pernapasan dari MG dapat menyebabkan VAP, meskipun sudah dilakukan pencegahan VAP dengan elemen bundle VAP dengan oral care menggunakan clorhexidin, profilaktik stress ulcer dengan OMZ 2x40 mg, sedasi dengan midazolam, head up pasien, tetapi masih terjadi VAP sehingga akan mempersulit penyembuhan pasien, namun dengan terapi antibiotik yang sesuai dengan hasil kultur maka VAP akan teratasi.

Tata laksana gagal napas pada krisis miastenia kegagalan pernapasan adalah kondisi klinis yang terjadi ketika sistem pernapasan gagal mempertahankan fungsi utama dalam pertukaran gas, dengan parameter $\mathrm{PaO}_{2}$ lebih rendah dari $60 \mathrm{mmHg}$ dan/atau $\mathrm{PaCO}_{2}$ lebih tinggi dari $50 \mathrm{mmHg}$ atau PF Rasio $<300$. Disfungsi respirasi/gagal napas pada krisis miastenia terjadi akibat gangguan ventilasi yang berupa otot-otot jalan napas atas dan bawah melemah, atau kombinasi kedua grup otot tadi. Disfungsi respirasi juga dapat terjadi karena obstruksi jalan napas atas akibat orofaringeal kolaps atau obstruksi karena lidah yang jatuh dan oleh otot-otot pernapasan yang lemah untuk melawan penyumbatan jalan napas. ${ }^{10}$ Tipe gagal napas pada krisis miastenia adalah gagal napas tipe 2, yaitu hypercapnic $\left(\mathrm{PCO}_{2}\right.$ lebih 50) gangguan ventilasi akibat gangguan pada sistem saraf tepi: otot pernapasan dan kelemahan dinding dada seperti pada kasus ini.

Efisiensi paru dalam melakukan respirasi dapat dievaluasi lebih lanjut dengan mengukur gradien $\mathrm{PO}_{2}$ alveolar-arteri. Perbedaan ini dihitung dengan persamaan berikut: $\mathrm{PAO}_{2}=$ $\mathrm{FiO}_{2} \times\left(\mathrm{PB}-\mathrm{PH}_{2} \mathrm{O}\right)-\mathrm{PACO}_{2} / \mathrm{R} . \mathrm{PAO}_{2}$ adalah $\mathrm{PO}_{2}$ alveolar, $\mathrm{FiO}_{2}$ adalah konsentrasi fraksional oksigen dalam gas inspirasi, PB adalah tekanan barometrik, $\mathrm{PH}_{2} \mathrm{O}$ adalah tekanan uap air pada $37^{\circ} \mathrm{C}, \mathrm{PACO}_{2}$ adalah $\mathrm{PCO}_{2}$ alveolar (diasumsikan sama dengan $\mathrm{PaCO}_{2}$ ), dan $\mathrm{R}$ adalah perbandingan pertukaran pernapasan. $\mathrm{R}$ bergantung pada konsumsi oksigen dan produksi karbondioksida. Saat diam, rasio 
$\mathrm{VCO}_{2}$ ke ventilasi oksigen $\left(\mathrm{VO}_{2}\right)$ sekitar 0,8. Persamaan di atas dapat digunakan untuk membedakan 2 tipe gagal napas. ${ }^{12.15}$ Pada pasien ini utamanya adalah gagal napas tipe 2 hiperkapnik karena terjadi hipoventilasi dengan $\mathrm{PaCO}_{2}$ dan $\mathrm{PaO}_{2}$ and alveolar arterial $\mathrm{PO}_{2}$ gradient normal sekitar 0,8 .

Manajemen respirasi pada kasus ini lebih diutamakan untuk mengatasi hiperkapnia karena krisis miastenia. Utamanya adalah intubasi dengan bantuan ventilasi mekanik meskipun dapat juga digunakan noninvasif ventilasi (NIV) bila syarat-syaratnya terpenuhi. Pasien ini kemungkinan memerlukan bantuan ventilasi lebih dari 3 hari sehingga NIV tidak dipilih. Sekitar $66 \%$ sampai $90 \%$ pasien krisis miastenia memerlukan intubasi dan ventilasi mekanik utamanya bila terjadi obstruksi jalan napas atas atau disfagia berat dengan risiko aspirasi.$^{12}$

Pengaturan ventilator awal dengan mode assisted (assisted control/volume control) dengan tidal volume 8-10 cc/kgBB predicted body weight (PBW) dan pressure support 8-15 $\mathrm{cm} \mathrm{H}_{2} \mathrm{O}$. Hal ini untuk mencegah atelektasis dan meminimalkan work of breathing (WOB) pasien. Besar dukungan yang dibutuhkan sangat bergantung pada kondisi pasien. ${ }^{11}$ Selain itu, dilakukan strategi proteksi paru, strategi ini adalah mengoptimalkan bantuan ventilasi mekanik untuk menghindari terjadinya volutrauma, atelektrauma, hiperoksia, aspirasi pnemonia dengan mengatur seting ventilasi: volume tidal $<6,5 \mathrm{~mL} / \mathrm{kg} \mathrm{BB}$, PEEP $5-24 \mathrm{~cm}$ $\mathrm{H}_{2} \mathrm{O}$, plateu pressure $<30 \mathrm{~cm} \mathrm{H}_{2} \mathrm{O}$, kurangi $\mathrm{FiO}_{2}$ untuk mencapai saturasi 88-95\%, dan angkat kepala $30-45^{0}$ dari tempat tidur. ${ }^{11-13}$

Neuro muscular blocking agent (NMBA) memang sebaiknya digunakan di awal untuk dukungan penuh bantuan ventilasi mekanik. Nondepolar agen seperti veuronium lebih disarankan daripada depolar agen seperti succynil cholin karena terkait dengan jumlah reseptor AChR postsinaptik fungsional untuk transmisi neuromuskular. ${ }^{11}$ Pada pasien ini awal masuk diberikan atrakurium untuk NMBA untuk dukungan vetilasi mekanik dan selanjutnya diturunkan dan diberhentikan penggunaannya.
Pengukuran forced vital capasity (FVC) mungkin merupakan pengukuran yang paling berguna. Jika FVC normal dan pasien dispnea menunjukkan bahwa ada hal lain yang sedang terjadi (mis. emboli paru, gagal jantung). Hal ini juga menunjukkan bahwa pasien mungkin tidak memerlukan perawatan ICU untuk miastenia gravis. Jika FVC sangat rendah (mis. $<30 \mathrm{cc} / \mathrm{kg}$ ) mendukung diagnosis krisis miastenia dan perlu ICU untuk pemantauan intensif. Fungsi lainnya pengukuran FVC adalah menentukan respons terapi. Respons terapi dilakukan dengan mengukur FVC dua atau tiga kali sehari. Pada pasien ini awalnya FVC memang rendah sehingga memerlukan ICU, namun dapat respons dengan terapi sehingga di akhir perawatan ICU, FVC normal dan pasien tidak dispnea lagi, pasien ini hanya diperiksa saat pasien datang dan saat di ICU.

Weaning ventilasi seharusnya segera dimulai begitu ada perbaikan klinis pasien yang dicirikan dengan vital capacity pasien yang dapat mencapai lebih dari $15 \mathrm{~mL} / \mathrm{kgBB}$. Pasien segera diubah ke mode spontan dengan pressure support dengan triger dari pasien sendiri dan diturunkan secara bertahap sampai ke pengaturan minimal, tetapi bila pasien masih gagal weaning dapat disetting ulang ke mode ventilasi assisted. Rerata pasien dapat diekstubasi setelah 13 hari atau kurang dari dua minggu (bergantung pada kondisi pasien), reintubasi dapat terjadi pada sekitar $25 \%$ pasien krisis miastenia yang diekstubasi, ventilator pada pasien ini dapat diubah ke mode spontan pada perawatan di ICU hari ke-4, dan weaning ventilator setelah 14 hari perawatan, dan pada perawatan hari ke-17 dapat pindah ruangan.

Setelah diagnosis miastenia gravis dapat ditegakkan maka selanjutnya melaksanakan terapi dan reevaluasi. Ada beberapa terapi yang tersedia untuk membantu mengurangi kelemahan otot yang terjadi:

Timektomi: tindakan operasi ini untuk menghilangkan kelenjar timus (yang sering tidak normal pada individu miastenia gravis). Meskipun mekanisme pasti kepekaan automatis terhadap AChR tidak jelas, kelainan kelenjar timus (hiperplasia dan neoplasia) 
hampir pasti memainkan peran pada sebagian besar pasien MG. Hiperplasia timus ditemukan pada sekitar 15\% pasien miastenia gravis dan 32\% pasien krisis miastenia. Pasien MG dengan hiperplasia timus harus diobati dengan timektomi. Satu penelitian retrospektif menemukan bahwa pasien miastenia gravis yang telah menjalani timektomi memiliki insiden lebih sedikit terjadi krisis miastenia dan episode yang tidak terlalu parah. ${ }^{15}$ Pasien ini adalah laki-laki usia 33 tahun, tidak ada timoma sehingga tidak dilakukan timektomi.

Obat antikolinesterase (mestinon atau piridostigmin): memperlambat pemecahan asetilkolin pada sambungan neuromuskular sehingga akan meningkatkan transmisi neuromuskular dan meningkatkan kekuatan otot. Respons respirasi spontan dan peningkatan volume tidal diharapkan terjadi pada pemberian injeksi piridostigmin ini dan dipantau dengan pengukuran kadar AChR antibody serum sebelum dan sesudah terapi. Piridostigmin dapat diberikan secara intravena, selalu berhati-hati untuk munculnya efek samping antikolinergik (misalnya peningkatan sekresi, bradikardia). Pada pasien ini digunakan neostigmin metilsulfat $50 \mathrm{mg} /$ hari dikombinasikan dengan atrofin sulfat 1,25 $\mathrm{mg} /$ hari untuk mengatasi efek sampingnya.

Obatimunosupresif: berguna meningkatkan kekuatan otot dengan menekan produksi antibodi abnormal (prednison, azathioprine, mycophenolate mofetil, takrolimus, dan rituximab). Pada pasien ini dipergunakan metilprednisolon $62,5 \mathrm{mg} / 12 \mathrm{jam}$.

Plasmaferesis dan juga imunoglobulin intravena: plasmaferesis atau istilah lainnya adalah plasma exchange atau PLEX adalah prosedur plasma dipisahkan dari sel-sel darah dan diganti dengan fresh frozen plasma, produk darah atau plasma subtitute. Subtitute ini dapat berupa FFP, albumin, koloid, ataupun cairan lain. Konsepnya adalah fakta bahwa zat-zat yang beredar seperti racun atau auto antibodi terakumulasi dalam plasma. Volume plasma yang disubtitusi adalah $1-1,5 \mathrm{x}$ estimated plasma volume rumus $\mathrm{L}=0,07 \mathrm{x}$ BB(kg) x (1-Ht) ]. Pasien ini BB $45 \mathrm{~kg}, \mathrm{Ht}$ $40 \%$ maka jumlah plasma volumenya adalah
1,9 L sehingga volume plasma yang akan disubstitusi sekitar 1,9-2,85 L. Darah dipompa melalui filter secara kontinu 50-200 cc/menit. Proses filtrasi memakan waktu sekitar 3 jam untuk tiap serinya. ${ }^{9}$ Plasmaparesis dilakukan 5 sampai 7 kali untuk setiap siklus terapi standar. Dapat dilakukan setiap hari atau selang satu hari. Kadar titer serum antibodi AChR dapat dijadikan indikator kemajuan terapi. Seharusnya AChR antibodi ini diukur sebelum dan sesudah terapi plasmaferesis. ${ }^{9}$ Pada pasien ini tidak dilakukan pengukuran kadar titer antibodi karena keterbatasan alat, pasien ini dilakukan plasmaparesis serial sebanyak 6 kali dengan teknik membran filtrasi dengan hasil luaran yang bagus, indikatornya adalah kemajuan klinis dengan parameter kelemahan otot mengalami perbaikan, menggenggam semakin kuat. Pemeriksaan serologi antibodi asetilkolinesterase reseptor (pengukuran kadar titer antibodi) sebelum dan sesudah terapi tidak dilakukan karena keterbatasan alat, dan pada pasien ini juga tidak terjadi komplikasi yang berhubungan dengan akses vaskular, hipokalsemia, hipotensi, koagulopati, maupun alergi terhadap blood products atau filter.

Berdasar atas riwayat pengobatan yang sebelumnya pasien ini merupakan kasus baru, yaitu penderita yang belum pernah mendapat pengobatan OAT atau sudah pernah menelan OAT kurang dari satu bulan (30 dosis harian). Pasien ini menggunakan OAT kombinasi dosis tetap (fixed dose combination) yang terdiri atas: empat obat antituberkulosis dalam satu tablet (4FDC), yaitu rifampisin $150 \mathrm{mg}$, isoniazid 75 $\mathrm{mg}$, pirazinamid $400 \mathrm{mg}$ dan etambutol 275 mg dan Dua obat antituberkulosis dalam satu tablet (2FDC), yaitu rifampisin $150 \mathrm{mg}$ dan isoniazid $75 \mathrm{mg}{ }^{6}$

Pasien sudah mengonsumsi OAT sejak bulan Agustus (3 bulan) sehingga saat datang pasien sedang dalam pengobatan fase lanjutan dengan regimen FDC rifampisin dan isoniazid selama empat bulan. Penggunaan streptomisin sebagai terapi TB dapat sebagai pencetus krisis miastenia.

Sementara itu, untuk diagnosis ventilator associated pneumonia atau VAP ditegakkan 
dengan bukti pneumonia yang terjadi $>48$ jam setelah intubasi endotrakeal, berdasar atas ditemukan infiltrat pada foto rontgen toraks, ditambah sekret purulent, ronki pada auskultasi paru, dan leukositosis (14.290 sel/ $\mathrm{mm}^{3}$ ). Selain itu, ditemukan bakteri patogen pada hasil kultur dan uji resistensi berupa: klebsiella pneumoniaess pneumoniae.

Perhitungan lain berdasar atas guideline ASPEN dan ESPEN, kebutuhan kalori diberikan berdasar atas hasil pengukuran kalorimeter indirek. Pada pasien ini karena belum ada alat pengukurnya kami gunakan penghitungan kebutuhan energi berdasar atas berat badan. Perhitungannya adalah: (20-25 kcal/kgBB/ hari kalori dan 1,5 g/kgBB protein pada fase akut, 25-30 kcal/kgBB/hari kalori, dan 1,5$2,5 \mathrm{~g} / \mathrm{kgBB}$ protein pada fase anabolik. ${ }^{8}$ Pasien memiliki berat badan $45 \mathrm{~kg}$ sehingga fase akutnya perlu $1.125-1.350 \mathrm{kcal} /$ hari dengan protein 90 gram, diberikan secara enteral per sonde terbagi dalam 4-6x pemberian sehari. Saluran cerna baik, tidak ada residu, dan peristaltik baik. Imunonutrisi (selenium, arginin, glutamin, karnitin, asam lemak omega 3) tidak kami berikan karena memang evidence base tidak terbukti mendukung perbaikan outcome.

Krisis miastenia terjadi pada sekitar $20 \%$ pasien miastenia gravis generalisata. Selama bertahun-tahun karena perubahan pengobatan, prognosis, dan angka mortalitas pasien juga ikut berubah lebih baik. Kemajuan pengobatan saat ini yang menggabungkan agen inhibitor kolinesterase, obat imunosupresif, plasmaferesis, imunoterapi, dan perawatan suportif di unit perawatan intensif, sebagian besar pasien miastenia gravis memiliki rentang hidup yang hampir normal. Morbiditas yang terjadi adalah akibat gangguan kekuatan otot yang dapat menyebabkan aspirasi, dan peningkatan kejadian pneumonia, bahkan terjadi kegagalan pernapasan.

Pasien mulai merasakan ada perbaikan setelah hari ke-3 perawatan ICU, yaitu setelah plasmafaresis yang kedua dilakukan dengan bertambahnya kekuatan otot di seluruh badan, sesak napas berkurang, pandangan mata yang sudah tidak dobel lagi, serta keluhan sulit menelan berkurang. Objektif pasien: perbaikan klinis dari hari ke hari, hemodinamik stabil. Bantuan ventilasi mekanis dikurangi secara bertahap. Hari ke-3 sudah mulai weaning mode ventilasi dan berhasil dilakukan spontaneous breathing trial (SBT), hari ke-15 pasien dapat menggunakan T-piece tracheostomy, hari ke 18 bisa pindah dari ICU. Laboratoris perbaikan, hasil analisis gas darah dengan oksigenasi $\mathrm{PaO}_{2}$ meningkat dan $\mathrm{PCO}_{2}$ berkurang di bawah $50 \mathrm{mmH}_{2} \mathrm{O}$, gangguan keseimbangan asam basa dan elektrolit juga sudah terkoreksi, serta radiologis ada perbaikan signifikan.

\section{Simpulan}

Deteksi dini krisis miastenia dan penyebabnya melalui anamnesis terperinci dan pendekatan medis yang sesuai adalah penting. Pada pasien krisis miastenia, kondisi yang mengancam jiwa adalah gagal napas karena otot pernapasan melemah sehingga intubasi endotrakeal dan bantuan ventilasi mekanik harus segera diberikan perawatan agresif untuk faktor pencetus, yaitu tuberkulosis paru dan faktor penyulit VAP serta rehabilitasi dini juga sangat penting untuk meningkatkan keberhasilan terapi. Pengelolaan dilakukan dengan guideline terkini krisis miastenia, tuberkulosis paru, dan VAP. Saat ini plasmaferesis masih merupakan standar terapi yang efektif, efisien, dan cepat untuk terapi krisis miastenia, di samping terapi imunomodulator yang lain. Dukungan nutrisi yang adekuat juga turut membantu kesembuhan pasien. Dengan kemajuan terapi saat ini, pasien krisis miastenia mempunyai prognosis harapan hidup yang lebih baik dengan penurunan angka mortalitas pasien dari 75\% menjadi 3-4\% dalam 4 dekade ini.

\section{Daftar Pustaka}

1. Farkas J. Myasthenia gravis and myasthenic crisis. Internet Book of critical care [diunduh 12 September 2019]. Tersedia dari: https://emcrit.org/ibcc/ myasthenia/.

2. Dewanto G, Suwono, WJ, Riyanto B, Turana Y. Panduan praktis diagnosis dan 
tatalaksana penyakit saraf. Jakarta: EGK; 2019.

3. Sathasivam S. Diagnosis and management of myasthenia gravis. Progress Neurol Psychi. 2014;1:6-14.

4. VerninoS,LennonVA.Autoantibodyprofiles and neurological correlations of thymoma. Clin Cancer Res. 2004;10(21):7270-5.

5. Ghandi K, Moore A, Rosiere, L. Management of myasthenia crisis in the ED [internet]. 2019 [diunduh 13 September 2019]. Tersedia dari: http://www.nuemblog. com/blog/myasthenia.

6. Departemen Kesehatan RI. Pedoman diagnosis dan penatalaksanaan tuberkulosis di Indonesia. Jakarta: Depkes RI; 2013.

7. Ou SM, Liu CJ, Chang YS, Hu YW, Chao PW, Chen TJ, dkk. Tuberculosis in myasthenia gravis. Intern J Tubercul Lung Dis. 2013;17(1):79-84.

8. Pangalila FJ, Priyanti ZS, Crisma AA, Lilil S. Enty. Pedoman antibiotik empirik di ruang rawat intensif. Edisi pertama. Jakarta: PERDICI; 2019. hlm. 22-36.

9. Pradian E. Plasmaparesis. Dalam: Pradian E, Maskoen TT, Mansjoer A, Sugiarto A, penyunting. Continous renal replacement therapy (CRRT) \& plasmapheresis. Jakarta: PERDICI; 2018. hlm. 28-33.

10. Wendell L, Levine JM. Myasthenic crisis. Neurohospitalist. 2011;1(1):16-22.

11. Godoy D, Mello L, Masotti L, Napoli M. The myasthenic patient in crisis: an update of the management in Neurointensive Care Unit. Arquivos Neuro-Psiquiatria. 2013;71(9A):627-39.

12. Lindberg DM. Lung protective strategy for acute respiratory distress syndrome saves lives. NEJM. 2017;1(1):3-17.

13. Koroshetz WJ. National institute of neurogical disorders and stroke [internet].
2019 [diunduh 12 September 2019]. Tersedia dari: www.myastenia.org

14. Meriggioli M, Sanders D. Muscle autoantibodies in myasthenia gravis: beyond diagnosis?. Expert Rev Clin Immunol. 2012;8(5):427-38.

15. Sanders D, Wolfe G, Benatar M, Evoli A, Gilhus N, Illa I, dkk. International consensus guidance for management of myasthenia gravis. Neurology. 2016;87(4):419-25.

16. Venkataramaiah S, Kamath S. Management of myasthenia gravis. J Neuroanaesthesiol Crit Care. 2019;06(02):153-9.

17. Kalil A, Metersky M. Management of adults with hospital acquired and ventilator associated pneumonia: clinical practice guidelines by the Infectious Disease Society of America and American Thorax Society. Clin Infect Dis. 2016;63(1):1-51.

18. Rovina R. Prinsip penggunaan antibiotik pada penyakit kritis. Dalam: Pangalila FJV, penyunting. Penatalaksanaan infeksi pada penderita penyakit kritis. Edisi ke-1. Jakarta: PERDICI; 2013. hlm. 47-55.

19. Yang KS, Yamaji K. Plasma adsorption in critical care. Ther Aphen. 2002;6(3):1848.

20. Mandawat A. Outcome of plasmapharesis in myasthenia ravis: delayed therapy is not forable. Muscle Nerve. 2011;43(4):57884.

21. Gelfand EW. Intravenous immune globulin autoimmune and inflammatory diseases. N Engl J Med. 2012;367:2015-25.

22. Thomas EH, Bronze MS. Tuberculosis (TB) treatment and management. Medscape. 2020;21(2):28-46.

23. Wardhani RA. Patofisiologi diagnosis dan dlasifikasi TBC. Departemen Ilmu Kedokteran Komunitas Okupasi dan Keluarga. Jakarta: FK UI; 2002. 